\title{
FOOD CONTAMINATED BY PESTICIDES: A BRAZILIAN SITUATION OVERVIEW
}

\author{
Contaminação de Alimentos por Pesticidas: Uma Análise do Caso Brasileiro
}

\begin{abstract}
Consumers are becoming increasingly demanding about products quality, including new decision variables at their purchases time. Information on nutritional aspects and the use of pesticides has changed consumer preferences. The new information strategies emerged in response to new consumer's behavioral characteristics and new competition characteristics of the food market. These strategies privilege the use of quality signals, such as labeling, traceability, certification, brand names and adoption of minimum quality standards. The main feature of Brazilian markets is the lack of minimum standards and strong information asymmetries. The market for fresh food is affected by the indiscriminate use of pesticides. The information analysis gathered by the Program for Pesticide Residue Analysis in Food (PARA) found a very worrying situation in Brazil. In this sense, with this paper, our aim is to bring more information about the pesticides contamination in the fresh food markets in Brazil. Transaction Cost Economics is adopted as a theoretical framework to examine the coordination among the agents on the chain and seek sustainable alternatives to reduce the excessive use of pesticides in food production.
\end{abstract}

Eduardo Luiz Machado

Universidade Federal de São Paulo

eduluizmachado@yahoo.com.br

Priscila Cristini dos Santos

Universidade Federal de São Paulo

edumach@gmail.com

Recebido em: 11/07/2016. Aprovado em: 02/08/2017

Avaliado pelo sistema double blind review

Avaliado científico: Renato Silvério Campos

DOI: $10.21714 / 2238-68902017 v 19 n 2 p 075$

\section{RESUMO}

Consumidores estão ficando cada vez mais exigentes quanto a qualidade dos produtos, incluindo novas variáveis de decisão no momento de sua compras. Informações a respeito de aspectos nutricionais e a utilização de pesticidas têm alterado a preferências dos consumidores. As novas estratégias de informação emergiram em resposta às novas características comportamentais do consumidor e às novas características de competição do mercado de alimentos. Essas estratégias privilegiam o uso de sinais de qualidade, como rotulagem, rastreabilidade, certificação, nomes de marcas e adoção de padrões mínimos de qualidade. A principal característica do mercado brasileiro é a falta de padrões mínimos e as assimetrias de informação fortes. O mercado de alimentos frescos é afetado pelo uso indiscriminado de pesticidas. A análise das informações obtidas pelo Programa de Análise de Resíduos de Pesticidas em Alimentos (PARA) encontrou uma situação muito preocupante no Brasil. O objetivo deste trabalho é trazer mais informações sobre a contaminação de pesticidas nos mercados de alimentos frescos no Brasil. A Economia de Custos de Transação é adotada como um marco teórico para examinar a coordenação entre os agentes na cadeia e buscar alternativas sustentáveis para reduzir o uso excessivo de pesticidas na produção de alimentos.

Keywords: Agriculture, Food, Health, Pesticide and environment.

Palavras-chave: Agricultura, Alimento, Saúde, Agrotóxico e meio Ambiente.

\section{INTRODUTION}

Modern consumers evaluate several food products attributes before purchasing: price, quality, freshness, taste, practicality and nutritional contents are analyzed in order to provide maximum benefits at lower costs. Wider spread and easier access to health and food security information brought to consumers new parameters that help rearrange their preferences.
The new information strategies emerged in response to consumer's new behavioral characteristics and food market new competition characteristics, including the use of some quality signals such as labeling, traceability, certification and brand names (RAO; MONROE, 1989).

On the other hand, the use of pesticides in Brazil grows every year to increase the productivity in agriculture. According to the World Health Organization (WORLD 
HEALTH ORGANIZATION, 2010), pesticides are chemical compounds that are used to kill pests that damage crops. However, pesticides are toxic to humans and should be used safely and properly discarded.

Recent researches show that Brazil is the largest consumer of pesticides in the world (CASSAL et al., 2014; RIGOTTO; VASCONCELOS; ROCHA, 2014). In addition, the impacts triggered by the use of pesticides cause several environmental problems such as soil and water contamination, instigating the ecosystem imbalance, as well as severe health problems human.

The fresh food market is directly affected by the indiscriminate use of pesticides. This market is one of the least developed in Brazil in terms of governance systems. There is no product standard, the quality is very variable, and the cooling system is almost nonexistent. The information system is deficient and the transactions between agents are marked by extreme uncertainty and quality control problems. A major attribute of transactions involving fresh produce is temporal and local specificity due to high perishability and low value/weight ratio.

According to the WHO (WORLD HEALTH ORGANIZATION, 2010), international conventions, Stockholm Convention on Persistent Organic Pollutants and the Rotterdam Convention on Prior Informed Consent (UNITED NATIONS ENVIRONMENT PROGRAMME, 2001), provide means for countries mitigate the exposure to toxic pesticides by population. Successful implementation of these conventions requires information about the incidence of pesticide exposures.

In Brazil, the Agência Nacional de Vigilância Sanitária (ANVISA), held since 2001, the pesticide residues monitoring in some fresh foods through the Program for Pesticide Residue Analysis in Food (PARA). These data are critical for the final consumer be informed about the quality of food consumed.

In this sense, with this paper, our aim is to bring more information about the pesticides contamination in the fresh food markets in Brazil. Transaction Cost Economics is adopted as a theoretical framework to examine the coordination among the agents on the chain and seek sustainable alternatives to reduce the excessive use of pesticides in food production.

\section{LITERATURE REVIEW}

\subsection{Characteristics of the Fresh Food Market}

Vegetables and fruits are hard to standardize because quality is difficult to measure objectively and varies with in the same lot of produce. In addition, consumer preferences are heterogeneous, increasing the complexity of defining the quality desired. Uncertainty about the quality is high, as this depends on seeds, production region, climate, season, and other factors (handling, transport, and storage conditions prior to reaching the final consumer). As produce is highly perishable and sensitive to weather conditions, its prices may be extremely variable, creating endogenous uncertainty. Coordination failure lead to maladjustments that may result in lower product value, higher costs, production losses and shortage (FARINA; MACHADO, 1999; MACHADO, 2002).

Analyzing the fresh off-season fruit market in France, Brousseau and Codron (1997) showed that markets and hybrid governance structures could be complementary in the vertical coordination of the fresh fruit system. Transaction cost economics provides the analytical framework to understand vertical coordination, which may embrace a diversity of complex arrangements. Furthermore, the vertical coordination systems proliferation may contribute to dimming price transparency, and preserving or even increasing information asymmetries.

According to Williamson (1996), there are three commonly recognized governance structures: market, hybrid contracting, and hierarchy. The hybrid mode arises from a bilateral dependency strong enough to require close coordination but not strong enough to justify full integration. That dependency comes, usually, from asset specificity, measurement problems, or complexity, which, along with uncertainty, increase transaction costs.

A major attribute of transactions involving fresh produce is temporal and local specificity due to high perishability and low ratio between value and weight. Both are not enough to command hybrid coordination unless combined to a required quality or delivery time contracted by the downstream segments of the chain. The perishability requires completing certain operations within a precise and often very short time span, which can be a factor of product differentiation that influences the value and sale ease. Thus, the seller's risk may be extremely high. (FARINA; MACHADO, 1999; MACHADO, 2002)

However, without a system that can trace back through the chain, it is difficult to assign responsibility for damages to the product and there is a tendency to transfer an undue share of market risk from operators to growers through lower prices or shipments return. Vertical coordination can be a mean of sharing risk and/or sharing income amongst the many agents contributing to the process (MÉNARD; VALCESCHINI, 2005). 
Quality is a key variable in marketing strategies in the fresh food chain. It requires highly specific investments and tight coordination among agents, with respect to the detailed standards definition, methods of production, and controls for guaranteeing the products conformity to what is signaled. Hybrid contracts improve quality and quantity control, but the market power imbalance may persist, and the distribution conflict preclude net benefits, that can be collected by cooperative behavior.

\subsection{Pesticides, Sustainability and Human Health}

Pesticide residues are the most important food safety concern in the fresh food supply chain. The Brazilian farmer considered the use of pesticides as a fundamental tool to ensure protection against low yields or the destructions of culture, but this excessive use has adverse impact on the environment and human health.

Environmental Protection Agency (ENVIRONMENTAL PROTECTION AGENCY, 2012) defines pesticides as chemicals or any substance or mixture of substances intended for preventing, destroying or controlling any pest, including vectors of human diseases or animals that cause harm or interfere in any way in the production, processing, storage, transport or marketing of food, agricultural products and wood products. In general, they are used in agriculture to combat pests, weeds and diseases in plants as well as vector control agents in public health programs and, to a lesser extent, livestock and forestry. According to the World Health Organization (WORLD HEALTH ORGANIZATION, 2010), pesticides are chemical compounds that are used to kill pests that damage crops.

The pesticides can be organic or inorganic and their formulation can be solid, liquid or paste. They are divided into four classes (I, II, III or IV) degrees of toxicity. Class I products are those with greater toxicity and risk to human health (BRASIL, 1998).

The use of pesticide in food production has caused serious environmental damages. Its application often not only affects crops, impacting directly on the imbalance in the food chain, damage to aquatic ecosystems (rivers, streams or groundwater), damage to the soil (preservation of natural features) and air. These impacts are sensitive to climate change since optimal pesticide application rates vary with weather and climate conditions.

Another serious consequence for its uncontrolled application is the impact on public health, especially for rural workers, who often handle this chemical without the necessary safety equipment.
According to Pelaez, Terra and Silva (2010) there are more than 366 active ingredients registered in Brazil for agricultural use, with more than 200 different chemical groups that give rise to 1458 formulated products for sale on the market. Herbicides represent $48 \%$ of the market, while insecticides and fungicides, respectively $26 \%$ and $22 \%$.

The National Information System Toxic Pharmacological shows that pesticides were responsible for $5.28 \%$ of human poisoning notifications in agriculture, totaling 5,253 cases in Brazil in 2009. As for the recorded deaths, the situation is even more alarming, with the record 171 cases, representing $41.81 \%$ of poisoning deaths.

In order to improve the quality of fresh produce, especially to reduce the excessive use of pesticides in production, investments must be made by each of agents, and their performance depends on a well-coordinated action. The effectiveness of this strategy consists in use of signaling mechanisms in the transactions involving products in nature, as the Program for Pesticide Residue Analysis in Food (PARA).

\section{PROGRAM FOR PESTICIDE RESIDUE ANALYSIS IN FOOD (PARA)}

In order to analyze the food quality, ANVISA started a project to monitor the amount of pesticide residues found in some types of fresh food. According to the Agência Nacional de Vigilância Sanitária (2008), the monitored cultures were chosen from the consumption data Search Family Budget Survey, these foods availability in distribution networks and the use of pesticides.

The first report published by the Agência Nacional de Vigilância Sanitária (2009) brought information between the years 2001 to 2007 covering 16 Brazilian states and 09 cultures. In later years, ANVISA individually published reports of the years 2008, 2009 and 2010. There were 15 states and 17 cultures analyzed in 2008, 25 states and 20 crops in 2009, 26 states and 18 crops in 2010, as shown in Table 1.

Table 1 shows that all food with result greater than zero, i.e., $94 \%$ of the total samples are considered harmful to health, since they are outside the permitted limit or else the presence of the substance that has been identified is not authorized by national legislation. This result is quite worrying, because it directly affects rural workers who handle the product and the final consumer who ingests it.

Table 1 show that some cultures have a high contamination by pesticides degree. Five important products in the Brazilian diet (lettuce, carrots, chicken, peppers and tomatoes) showed worrying results. 
TABLE 1 - Unsatisfactory samples for culture monitored by the PARA between 2001 and 2010 (\%)

\begin{tabular}{|c|c|c|c|c|c|c|c|c|c|c|c|c|c|}
\hline $\begin{array}{l}\text { CROP/ } \\
\text { YEAR }\end{array}$ & $\begin{array}{l}\text { Toxicological } \\
\text { Classification }\end{array}$ & $\begin{array}{l}2001 / \\
2002\end{array}$ & 2003 & 2004 & 2005 & 2006 & 2007 & 2008 & 2009 & 2010 & 2011 & 2012 & $\begin{array}{c}2013 / 2014 / \\
2015\end{array}$ \\
\hline Apple & II & 4,0 & 3,7 & 5,0 & 3,1 & 5,3 & 2,9 & 3,9 & 5,3 & 8,9 & No & 8 & 10 \\
\hline Banana & II & 6,5 & 2,2 & 3,6 & 3,1 & No & 4,3 & 1,0 & 3,5 & No & No & No & 0 \\
\hline Bean & II & - & - & - & - & - & - & 2,9 & - & 6,5 & 6 & 73 & 35 \\
\hline Beet & II & - & - & - & - & - & - & - & 32,0 & 32,6 & No & - & 13 \\
\hline Bell-pepper & II & - & - & - & - & - & - & 64,4 & 80,0 & 91,8 & 90 & No & 10 \\
\hline Cabbage & III & - & - & - & - & - & - & 8,2 & 20,5 & 6,3 & No & No & 24 \\
\hline Carrot & II & 0 & 0 & 19,5 & 11,9 & No & 9,9 & 30,4 & 24,8 & 49,6 & 67 & 33 & 21 \\
\hline Cole & II & - & - & - & - & - & - & - & 44,2 & 31,9 & No & - & 1 \\
\hline Cucumber & II & - & - & - & - & - & - & - & 54,8 & 57,4 & 44 & 42 & 17 \\
\hline Grape & III & - & - & - & - & - & - & 32,7 & 56,4 & - & 27 & 29 & 35 \\
\hline Lettuce & II & 8,6 & 6,7 & 14,0 & 46,5 & 28,7 & 40,0 & 19,8 & 38,4 & 54,2 & 43 & 45 & 1 \\
\hline Mango & II & - & - & - & - & - & - & 1,0 & 8,1 & 4,0 & No & No & 43 \\
\hline Onion & II & - & - & - & - & - & - & 2,9 & 16,3 & 3,1 & No & - & 3 \\
\hline Orange & I & 1,4 & 0 & 4,9 & 4,7 & 0 & 6,0 & 14,9 & 10,3 & 12,2 & No & 28 & 17 \\
\hline Papaya & II & 19,5 & 37,6 & 2,5 & 0 & No & 17,2 & 17,3 & 38,8 & 30,4 & 20 & - & 33 \\
\hline Pineapple & II & - & - & - & - & - & - & 9,5 & 44,1 & 32,8 & No & 41 & 0 \\
\hline Potato & II & 22,2 & 8,7 & 1,8 & 0 & 0 & 1,4 & 2,0 & 1,2 & 0,0 & No & - & 3 \\
\hline Rice & II & - & - & - & - & - & - & 4,4 & 27,2 & 7,4 & 16 & 1 & 32 \\
\hline Strawberry & I & 46,0 & 54,6 & 39,1 & No & 37,7 & 43,6 & 36,1 & 50,8 & 63,4 & No & 59 & 6 \\
\hline Tomato & II & 26,1 & 0 & 7,4 & 4,4 & 2,0 & 44,7 & 18,3 & 32,6 & 16,3 & 12 & 16 & 17 \\
\hline
\end{tabular}

Legend: "No": It means that no toxicological analysis was done; "-": It means it was not monitored in the year

Source: Prepared by the authors from Agência Nacional de Vigilância Sanitária (2009, 2010, 2011, 2012, 2016)

Between 2008 and 2015, twenty-five different substances were found in the analyzed samples. Noteworthy is the presence of Carbendazim and dithiocarbamate in the analyzed samples. However a described by the Agência Nacional de Vigilância Sanitária (2012), the Carbendazim is an insecticide and acaricide with toxicological classification III, i.e. moderately toxic and is authorized for cotton, citrus, beans, apples, soybeans and wheat. In the report from 2013 to 2015 there was a sharp fall to $1 \%$ this result. The reason for this decline was not stated in the report. (Figure 1)

Since the dithiocarbamate is a fungicide with toxicological classification II, or highly toxic and is allowed to rice, potato, tomato, and citrus crops.

The number of samples contaminated with pesticides in the production of carrot also showed a tendency to decrease in the analyzed period (Figure 2). There is a drop in the number of unsatisfactory samples from 2011 to 2015 , from $67 \%$ to $21 \%$.
Between 2008 and 2015, eight different substances in the analyzed samples were found. The substances found were Methamidophos and Chlorpyrifos. According to the Agência Nacional de Vigilância Sanitária (2012), the Methamidophos is an insecticide and acaricide with toxicological classification I, i.e., extremely toxic and is authorized for cotton, peanuts, potatoes, beans, soybean, tomato and wheat and its use is a discontinued process as Resolution RDC \# 01 of 14/01/2011. Moreover, Chlorpyrifos is an insecticide, ant killer and acaricide with toxicological classification II, i.e. highly toxic and is authorized for cotton, potato, coffee, barley, citrus, beans, apples, corn, pasture, sorghum, tomato and wheat.

For strawberry, there is a small drop in the number of unsatisfactory samples detected in 2011. In 2012, there was no crop analysis, and there was a considerable drop in the years 2013-2015, from 60\% to 10\%. Between 2008 and 2015, eighteen different substances in the analyzed samples were found (Figure 3). 


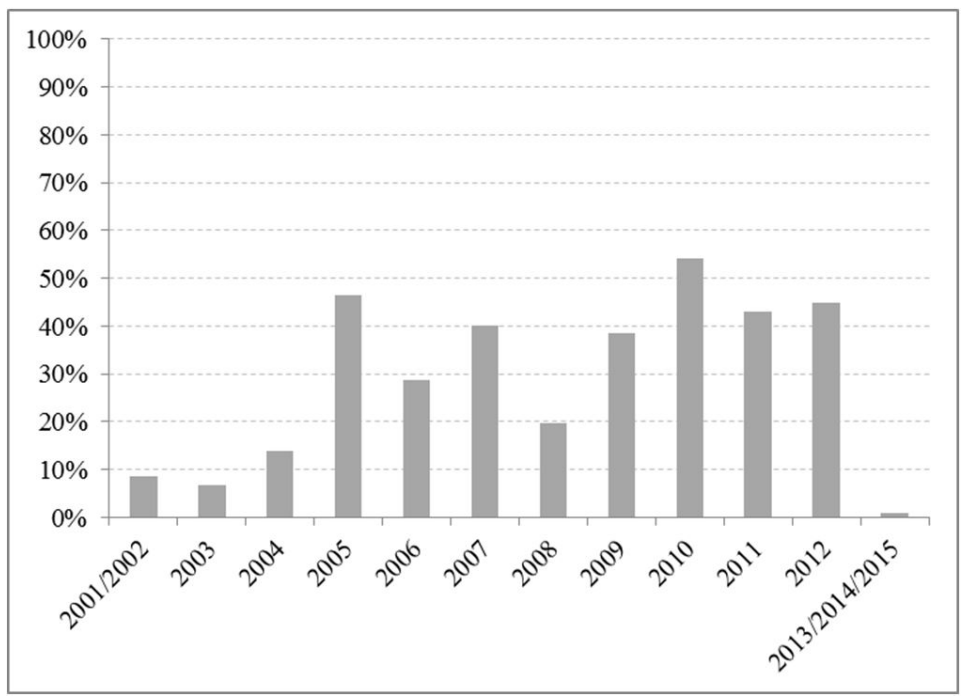

FIGURE 1 - Amount of contaminants in lettuce crop (\%)

Source: Prepared by the authors from Agência Nacional de Vigilância Sanitária (2009, 2010, 2011, 2012, 2016)

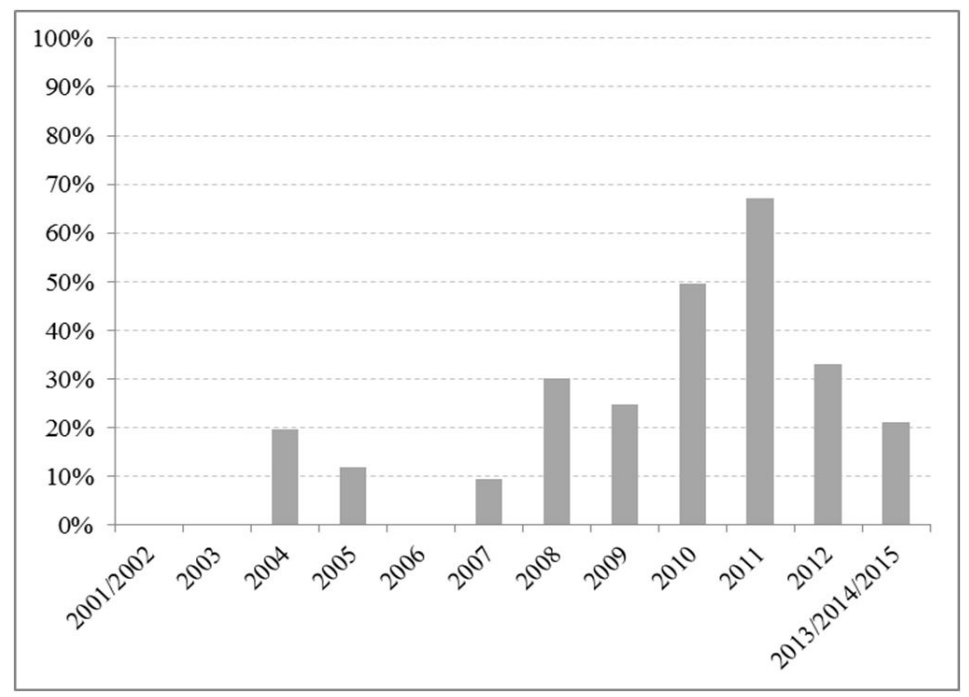

FIGURE 2 - Amount of contaminants in carrot crop

Source: Prepared by the authors from Agência Nacional de Vigilância Sanitária (2009, 2010, 2011, 2012, 2016)

The substances found were Endosulfan, Prochloraz and Phosmet. Endosulfan is an insecticide and acaricide with toxicological classification I, ie, extremely toxic and is authorized for cotton, coffee, sugarcane, soybean and its use is process discontinuity. The fungicide Prochloraz is a toxicologically I classification, or extremely toxic and it is allowed to onion, carrot, barley, watermelon, rose, tomato and wheat crops. Moreover, Phosmet is an insecticide and acaricide with toxicological classification I, i.e., extremely toxic and is authorized for citrus crops, apple and peach crops (AGÊNCIA NACIONAL DE VIGILÂNCIA SANITÁRIA, 2012).

The bell pepper situation is the most troubling of all. For this product, a linear increase in the number of samples contaminated with pesticides in between 2008 and 2015. In 2011, contamination occurred in 90,1\% of samples was observed. In 2012, there was no analysis of this crop, and there was a considerable drop in the years 2013-2015 (Figure 4). 


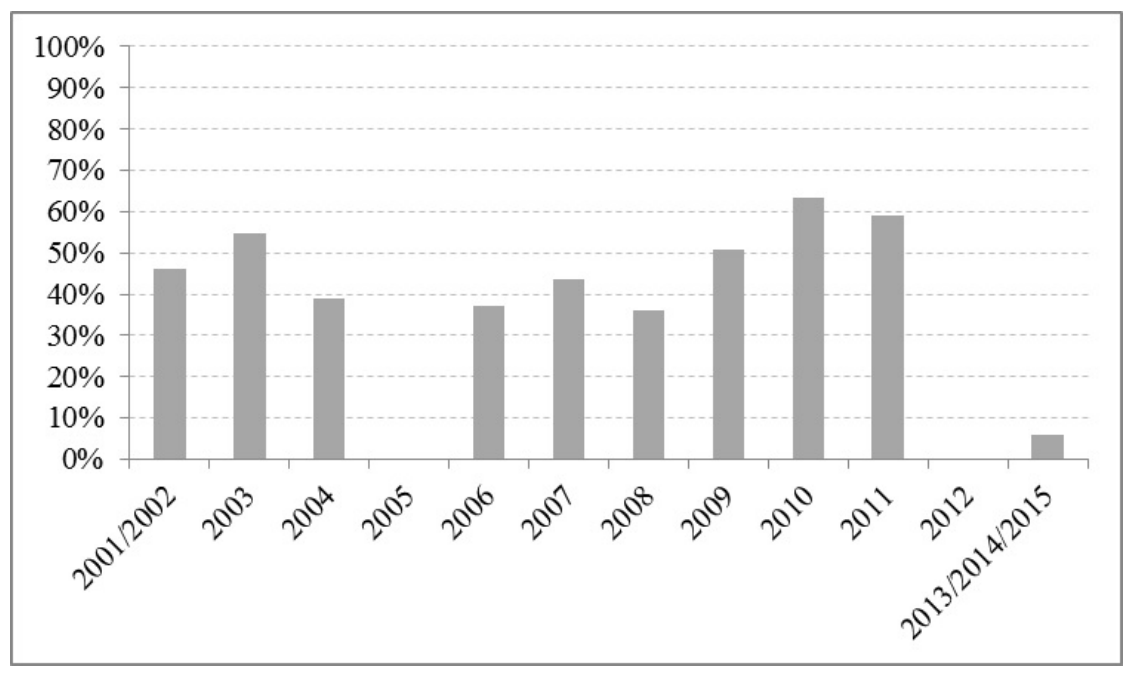

FIGURE 3 - Amount of contaminants in strawberry crop (\%)

Source: Prepared by the authors from Agência Nacional de Vigilância Sanitária (2009, 2010, 2011, 2012, 2016)

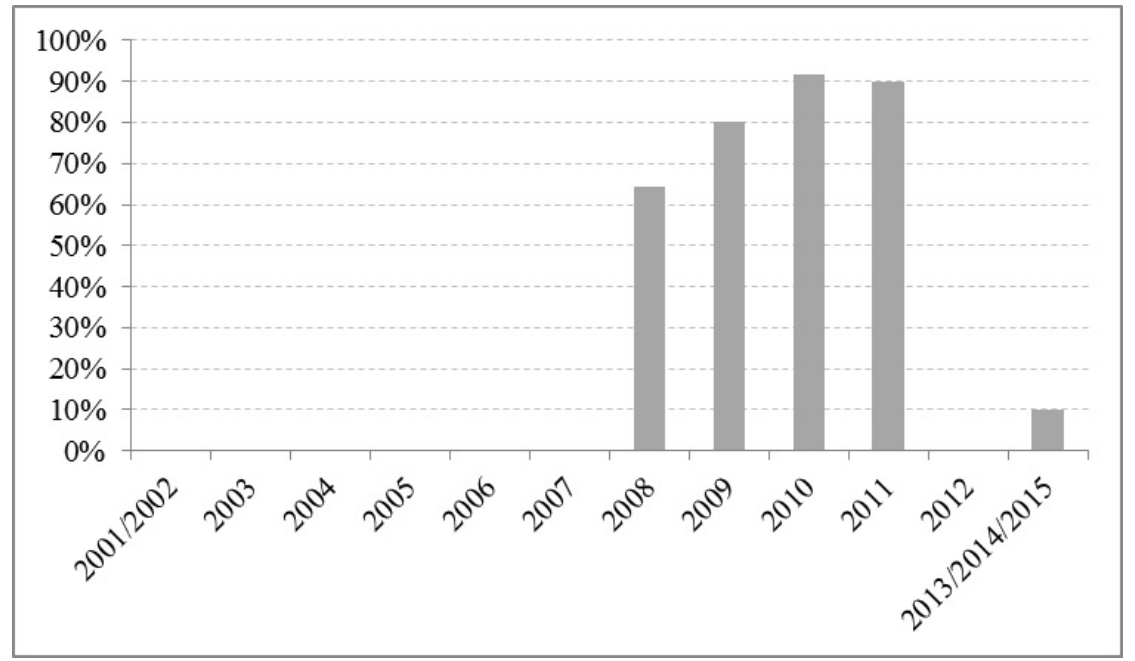

FIGURE 4 - Amount of contaminants in the bell pepper crop (\%)

Source: Prepared by the authors from Agência Nacional de Vigilância Sanitária (2009, 2010, 2011, 2012, 2016)

Between 2008 and 2015, twenty different substances in the analyzed samples were found. The substances found were Profenofos, Cypermethrin and Carbendazim.

Prophenophos is an insecticide and acaricide with toxicological classification II, i.e. highly toxic and it is authorized for cotton, peanuts, potatoes, coffee, onions, peas, beans, sunflower, cassava, watermelon, corn, cucumber, cabbage, soybeans, wheat and tomatoes. The Cypermethrin is an insecticide and ant killer with toxicological classification II, i.e. highly toxic and is authorized for cotton, peanuts, rice, potatoes, coffee, onions, citrus, peas, beans, snap beans, tobacco, cassava, watermelon, corn, cucumber, cabbage, soybeans and tomatoes. Moreover, Carbendazim is an insecticide and acaricide with toxicological classification III, i.e., moderately toxic and is authorized for cotton, citrus, beans, apples, soybeans and wheat (AGÊNCIA NACIONAL DE VIGILÂNCIA SANITÁRIA, 2012). 
In the tomato production, a large variation for samples contaminated with pesticides was observed in last decade. Between 2008 and 2015, seven different substances were found in the analyzed samples, highlighting the Chlorpyrifos (Figure 5).

As Agência Nacional de Vigilância Sanitária (2012), the Chlorpyrifos is an insecticide, ant killer and acaricide with toxicological classification II, i.e. highly toxic and it is authorized for cotton, potato, coffee, barley, citrus, beans, apples, corn, pasture, sorghum, tomato and wheat.

\section{CHALLENGES FOR PUBLIC POLICIES}

The data indicate a very worrying situation, since $78 \%$ of contaminants come from the use of pesticides not authorized by ANVISA. Furthermore, these chemicals are used in cultures where there is no clarity about the maximum allowable quantities or its effects on the physical environment and the risks to the human health.

In this sense, it is necessary ensure that the use of pesticides occurs as defined by the regulatory body and described on the label of the package. The rural workers' awareness about the risks of excessive use of pesticides has also a vital importance. Therefore, a major initiative would promote farmers training in good agricultural practices as regards the pesticides application. Such a measure would be important to reduce goods and people contamination rates.

Another important factor is to expand the information about the excessive use of pesticides in the fields. As discussed by Nelson (1970), limitations on consumer information regarding the product quality have negative effects on the market structure. Thus, farmers who produce products within the quality standards required by regulatory authorities should create signaling mechanisms to consumers.

Improving adequate monitoring infrastructure is another policy that should be encouraged. In this sense, Figure 6 shows the average number of samples analyzed by state, culture and year. The results show a considerable drop in the number of collected samples. This decrease is explained by the fact that there are only four laboratories capable of performing these analyzing, according to the Agência Nacional de Vigilância Sanitária (2012).

This fact highlights the lack of adequate infrastructure to achieve the objectives of the PARA. It is not representative for a program that provides great importance information to society.

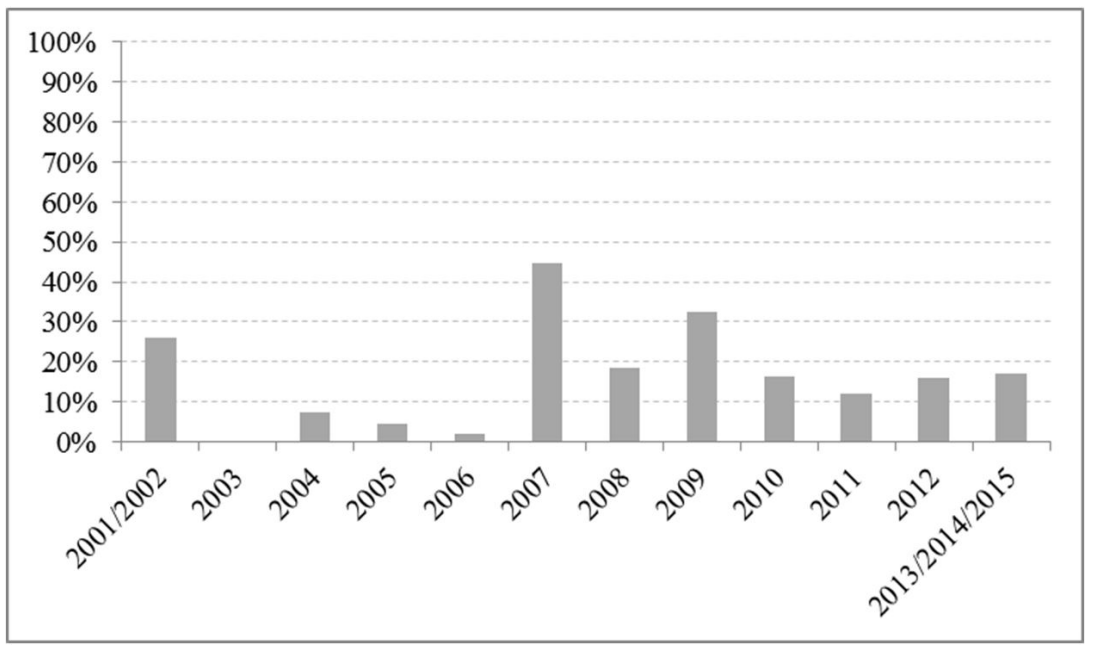

FIGURE 5 - Amount of contaminants in the tomato crop (\%)

Source: Prepared by the authors from Agência Nacional de Vigilância Sanitária (2009, 2010, 2011, 2012, 2016) 


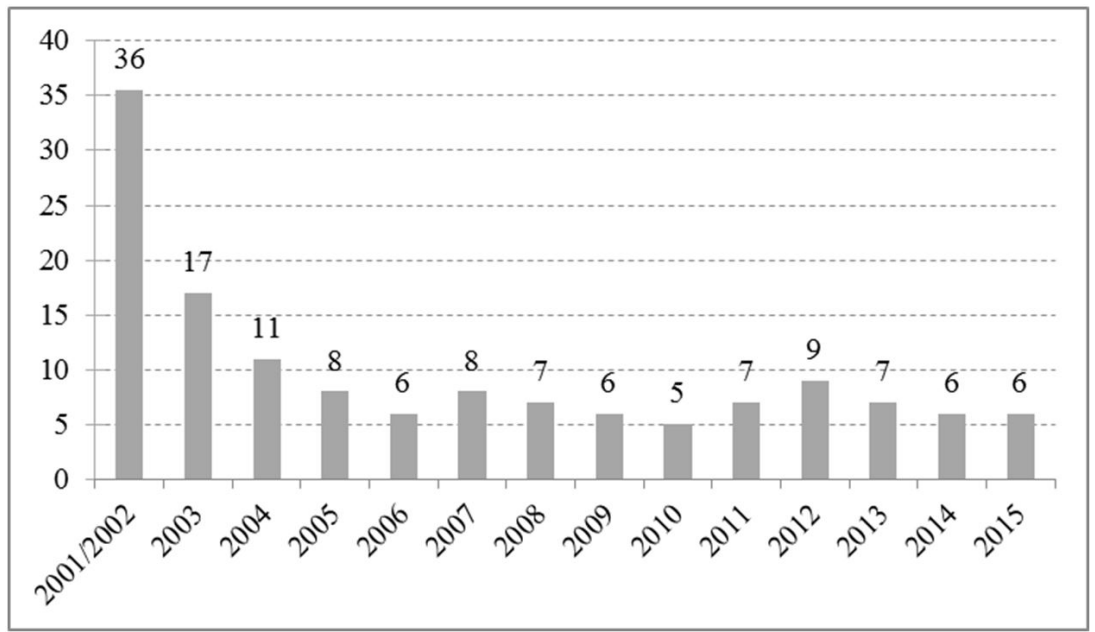

FIGURE 6 - Average number of samples analyzed by state, culture and year

Source: Prepared by the authors from Agência Nacional de Vigilância Sanitária $(2009,2010,2011,2012,2016)$

\section{FINAL CONSIDERATIONS}

The main feature of Brazilian fresh markets is the lack of minimum standards and very strong information asymmetries. Consequently, endogenous and exogenous uncertainties are high.

The analysis of information gathered by the PARA found a worrying situation in Brazil. In order to improve the fresh produce quality, especially to reduce the excessive use of pesticides in production, investments must be made in infrastructure and training.

The rapid and successful development of hybrid arrangements as endogenous solutions to information and control over the quality problems would be an important way to reduce the uncertainties and, consequently, the transaction cost. The increase in control and monitoring instruments may be responsible for the contamination reduction of fresh products in the recent period. However, this result may also be due to the reduction in the number of samples analyzed.

Introducing good agricultural practices implies minimizing the agrochemicals use and a traceability system implementation, becoming farmers more aware on environmental protection and on efficient use of resources and ensure the workers' health, safety and welfare.

\section{REFERENCES}

AGÊNCIA NACIONAL DE VIGILÂNCIA SANITÁRIA - ANVISA. Regularização de produtos - agrotóxicos.
Brasília: Anvisa, 2012. Disponível em: <http://portal. anvisa.gov.br/wps/content/Anvisa+Portal/Anvisa/Inicio/ Agrotoxicos+e+Toxicologia/Assuntos+de+Interesse/ Monografias $+\mathrm{de}+$ Agrotoxicos/Monografias $>$. Acesso em: 2 fev. 2016.

Programa de Análise de resíduos e agrotóxicos em alimentos: relatório das análises de amostras monitoradas no período de 2013 a 2015. Brasília: Anvisa, 2016. $246 \mathrm{p}$.

. Programa de análise de resíduos e agrotóxicos em alimentos: nota técnica para divulgação dos resultados do PARA de 2008. Brasília: Anvisa, 2009. 12 p.

Programa de análise de resíduos e agrotóxicos em alimentos: relatório de atividades 2009. Brasília: Anvisa, 2010. 22 p.

. Programa de análise de resíduos e agrotóxicos em alimentos: relatório de atividades 2010. Brasília: Anvisa, 2011.26 p.

BRASIL. Legislação Federal de agrotóxicos e afins. Brasília: Ministério da Agricultura, 1998. 184 p.

BROUSSEAU, E.; CODRON, J. M. The hybridization of governance structures: supplying French supermarkets with off-season fruits. In: SFER CONGRESS MODERN FOOD RETAILING, 1997, Montpellier-France. Apresentation... Montpellier: Universite Paris, 1997. 
CASSAL, V. B. et al. Agrotóxico: uma revisão de suas consequências para a saúde pública. Revista Eletrônica em Gestão, Educação e Tecnologia Ambiental, Santa Maria, v. 18, n. 1, p. 437-445, abr. 2014.

ENVIRONMENTAL PROTECTION AGENCY - EPA. Learn the issues: pesticide program. Washington: EPA, 2012. Disponível em: <http://www.epa.gov/pesticides/ about/index. htm>. Acesso em: 9 abr. 2012.

FARINA, E.; MACHADO, E. L. Government regulation and business strategies in brazilian fresh fruit and vegetable market. In: IAMA CONGRESS, 1999, Florence. Proceedings... London: IAMA, 1999.

MACHADO, E. L. O papel da reputação na coordenação vertical da cadeia produtiva de frutas, legumes e verduras frescos. 2002. 182 f. Tese (Doutorado em Economia) - Universidade de São Paulo, 2002.

MÉNARD, C.; VALCESCHINI, E. New institutions for governing the agri-food industry. European Review of Agricultural Economics, Amsterdam, v. 32, n. 3, p. 421-440, Sept. 2005.

NELSON, P. Information and consumer behavior. Journal of Political Economy, Chicago, v. 78, n. 2, p. 311-329, Mar./Apr. 1970.
PELAEZ, V.; TERRA, F. H. B.; SILVA, L. R. A regulamentação dos agrotóxicos no Brasil: entre o poder de mercado e a defesa da saúde e do meio ambiente. Revista de Economia, Curitiba, v. 36, n. 1, p. 27-48, jan./abr. 2010.

RAO, A. R.; MONROE, K. B. The effect of price, brand name and store name on buyers perception of product quality: an integrative review. Journal of Marketing Research, Chicago, v. 26, n. 3, p. 351357, Aug. 1989.

RIGOTTO, R. M.; VASCONCELOS, D. P.; ROCHA, M. M. Uso de agrotóxicos no Brasil e problemas para a saúde pública. Caderno de Saúde Pública, Rio de Janeiro, v. 30, n. 7, p. 1-3, jul. 2014.

UNITED NATIONS ENVIRONMENT PROGRAMME. Stockholm Convention on Persistent Organic Pollutants (POPs): text and annexes. Geneve: UNEP, 2001. 56 p.

WILLIAMSON, O. The mechanisms of governance. Oxford: Oxford University Press, 1996. 448 p.

WORLD HEALTH ORGANIZATION. The WHO recommended classification of pesticides by hazard and guidelines to classification: 2009. Geneve: World Health Organization, 2010. 81 p. 